\title{
Prompt Gamma Activation Analysis of the Nyírlugos obsidian core depot find
}

\author{
Zsolt Kasztovszky ${ }^{1}$, Katalin T. Biró ${ }^{2}$ and Zoltán Kis ${ }^{1}$ \\ 1. Nuclear Analysis and Radiography Department, MTA Centre for Energy Research, Budapest, Hungary. \\ Email: Kasztovszky: kasztovszky.zsolt@energia.mta.hu; Kis: kis.zoltan@energia.mta.hu \\ 2. Hungarian National Museum, Budapest. Hungary. Email: tbk@ace.hu
}

\begin{abstract}
:
The Nyírlugos obsidian core depot find is one of the most important lithic assemblages in the collection of the Hungarian National Museum (HNM). The original set comprised 12 giant obsidian cores, of which 11 are currently on the permanent archaeological exhibition of the HNM. One of the cores is known to be in Debrecen. The first publication attributed the hoard, on the strength of giant (flint) blades known from the Early and Middle Copper Age Tiszapolgár and Bodrogkeresztúr cultures, to the Copper Age. In the light of recent finds it is more likely to belong to the Middle Neolithic period. The source area was defined as Tokaj Mts., about $100 \mathrm{~km}$ to the NW from Nyírlugos. The size and beauty of the exceptional pieces exclude any invasive analysis. Using Prompt Gamma Activation Analysis (PGAA), we can measure major chemical components and some key trace elements of stone artefacts with adequate accuracy to successfully determine provenance of obsidian. Recent methodological development also facilitated the study of relatively large objects like the Nyírlugos cores. The cores were individually measured by PGAA. The results show that the cores originate from the Carpathian 1 sources, most probably the Viničky variety $(\mathrm{C} 1 \mathrm{~b})$. The study of the hoard as a batch is an important contribution to the assessment of prehistoric trade and allows us to reconsider the so-called Carpathian, especially Carpathian 1 (Slovakian) sources.
\end{abstract}

Keywords: obsidian; depot find; Hungary; Prompt Gamma Activation Analysis

\section{Introduction}

The obsidian core depot find from Nyírlugos, Eastern Hungary is one of the most important lithic assemblages in the collection of the Hungarian National Museum (HNM). The original set was comprised of 12 giant obsidian cores, of which 11 are currently on the permanent archaeological exhibition of the HNM (Figure 1.). One of the cores is known to be in Debrecen.

This unique find was published first by J. Hillebrand (1928) who attributed the hoard, on the strength of giant blades known from the Early and Middle Copper Age Tiszapolgár and Bodrogkeresztúr cultures, to the Copper Age. These long blades were, however, made of flint exclusively (Hillebrand 1929; later on especially Patay 1960).

Journal of Lithic Studies (2014) vol.1, nr. 1, p. 151-163

doi:10.2218/jls.v1i1.784

Published by the School of History, Classics and Archaeology, University of Edinburgh ISSN: 2055-0472. URL: http://journals.ed.ac.uk/lithicstudies/

This work is licensed under a Creative Commons Attribution 2.5 UK: Scotland License. 


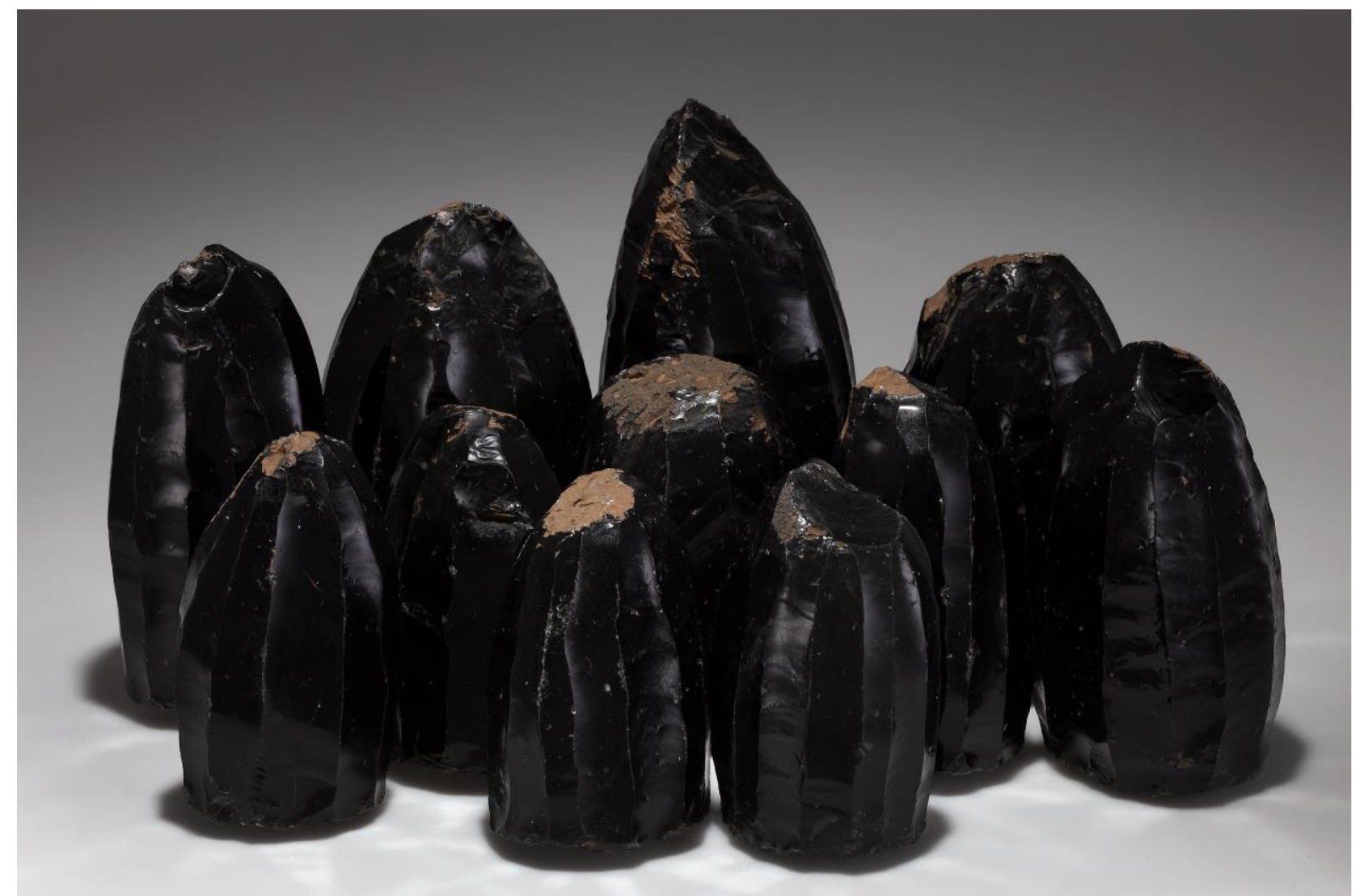

Figure 1. Depot find of obsidian blade cores from Nyírlugos. (Photo courtesy of Judit Kardos.)

The dating of the obsidian core depot find was essentially pushed back by several researchers into the Middle Neolithic (Patay 1976, Biró 1987).

In the current chronological system valid for Hungary, this means shifting the age of the depot find from 4500-3500 BC older part of the Copper Age back to 5300-5000 BC (Middle Neolithic period) (Visy et al. eds. 2003). Seemingly, the large obsidian nodules and consequently, large support flakes were depleted by the Copper Age as reflected by the generally small size of cores and nodules of obsidian known from the Late Neolithic lithic assemblages (Biró 1998) The discovery of giant cores from Middle Neolithic context (Bánesz 1991) supported also an earlier dating.

The source area was defined, on the basis of macroscopical inspection, as Tokaj Mts., about $100 \mathrm{~km}$ to the NW from Nyírlugos (Figure 2). In more recent descriptions the cores were attributed to the Carpathian 1 (Slovakian) sources, also on macroscopical grounds (Biró 1998).

\section{The objects}

The Nyírlugos hoard comprises large conical blade cores with perfect workmanship (Figure 3). Remains of the original cortex of the obsidian nodules were preserved on almost all of the pieces, mainly around the apex. The height of the largest core is $18.5 \mathrm{~cm}$ and the heaviest is more than $2.5 \mathrm{~kg}$, the smallest one is $10.5 \mathrm{~cm}$ large and its weight is $803 \mathrm{~g}$. Knowing that the average length of obsidian implements in this region is about $23 \mathrm{~mm}$ (HNM Lithotheca database; see also Biró 2001 and Biró 2003), we have to agree J. Hillebrand on the exceptional value of the Nyírlugos treasure for the prehistoric populace. The basic metrical data on the cores are summarised on Table 1. 


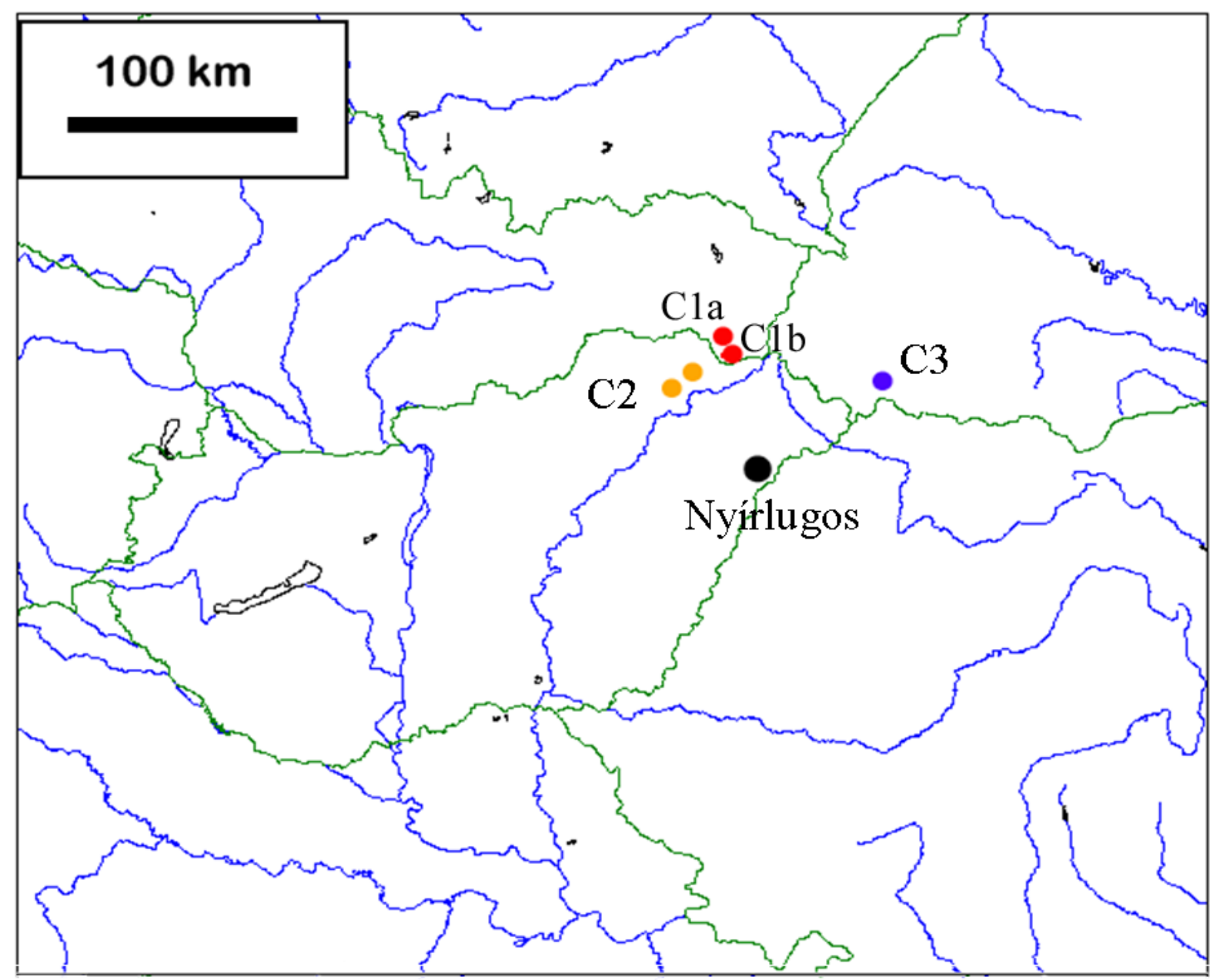

Figure 2. Location of the Carpathian obsidian sources and the Nyírlugos hoard. Key: C1 sources: red dots, C2 sources: orange dots, C3 source: blue dot. Rivers and lakes marked blue lines; current political boundaries with green lines. Map constructed in MapPad 2.0.

The size and beauty of the exceptional pieces exclude any invasive analysis. Fortunately, due to advantages of the non-destructive Prompt Gamma Activation Analysis (PGAA) analytical technique (Révay 2009), we are able to quantify major chemical components and some key trace elements of stone artefacts with adequate accuracy. The compositional data obtained by PGAA helps us to successfully determine provenance of obsidian (Kasztovszky \& Biró 2004, 2006; Kasztovszky et al. 2008). Furthermore, recent methodological development at the Neutron Induced Prompt Gamma-Ray Spectroscopy - Neutron Optics and Radiography for Material Analysis (NIPS-NORMA) experimental station operated by the Budapest PGAA Laboratory also facilitated the study of relatively large objects like the Nyírlugos cores without any sample preparation or destruction (Szentmiklósi et al. 2013).

The study of the hoard as a batch is an important contribution to the assessment of prehistoric trade and allows as to reconsider the so-called Carpathian, especially Carpathian 1 (Slovakian) sources.

\section{The Analytical Method}

PGAA was chosen to quantify all the major components and some important trace elements in a non-destructive way. PGAA - a bulk nuclear method - identifies chemical elements according to their characteristic $\gamma$-radiation emitted promptly after irradiation by slow neutrons. Since neutrons penetrate practically through the whole thickness of a few $\mathrm{cm}$ 
thick rock, it provides composition data characteristic for a few $\mathrm{cm}^{3}$ irradiated volume. In principle, PGAA enables to detect all the chemical elements, but the sensitivities for different elements vary within a wide range. Its most important feature from the point of archaeologists that there is no residual radioactivity or damage on any scale is caused during the investigation. In our obsidian provenance research, about 160 archaeological pieces from today's Hungary, Croatia, Romania, Serbia and Poland and 140 geological references from 12 major European source regions were analysed in the PGAA Laboratory of the Budapest Neutron Centre so far (Kasztovszky et al. 2008, 2009).
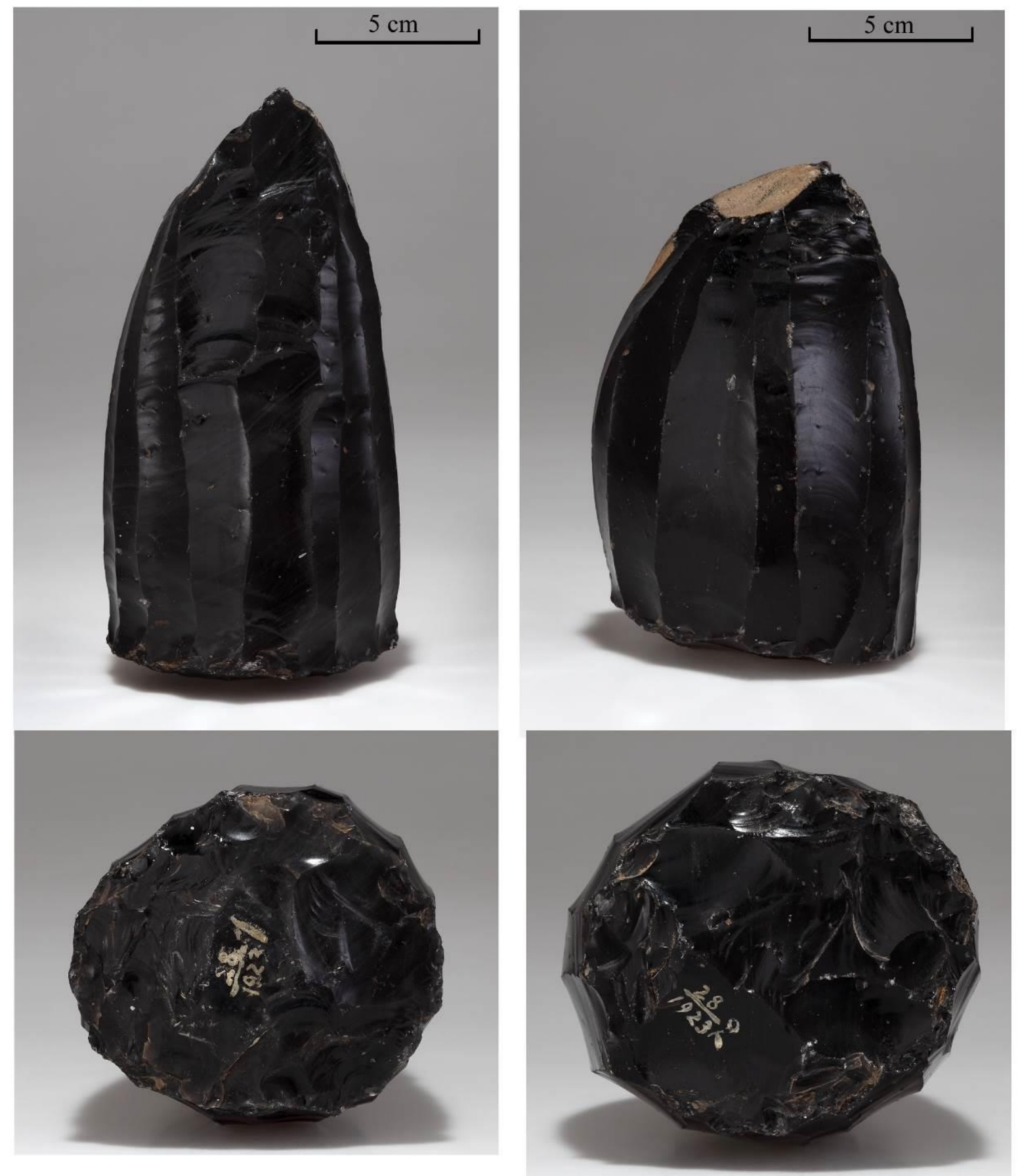

Figure 3. Typical conical blade cores from the Nyírlugos depot find (Inv. nr: HNM 1923.28.1-2). (Photo courtesy of Judit Kardos.) 
Table 1. Description and metrical data of the Nyírlugos cores.

\begin{tabular}{|c|c|c|c|}
\hline $\begin{array}{c}\text { Inventory } \\
\text { number } \\
\text { (HNM) }\end{array}$ & Description & $\begin{array}{l}\text { Dimensions } \\
\quad(\mathrm{cm})\end{array}$ & $\begin{array}{l}\text { Weight } \\
\text { (g) }\end{array}$ \\
\hline 1923.28.01. & $\begin{array}{l}\text { Large conical blade core, obsidian, with } 18 \text { blade } \\
\text { scars }\end{array}$ & $18.5 \times 9.7 \times 8.6$ & 2191 \\
\hline 1923.28.02. & $\begin{array}{l}\text { Large conical blade core, obsidian, with } 17+2 \text { blade } \\
\text { scars ( } 2 \text { from a former mantle). Cortex on the cusp } \\
\text { (approx. } 5 \% \text { ) }\end{array}$ & $16 \times 10.8 \times 9.8$ & 2525 \\
\hline 1923.28.03. & $\begin{array}{l}\text { Large conical blade core, obsidian, with } 14 \text { blade } \\
\text { scars. Traces of cortex on the cusp (approx. 1\%) }\end{array}$ & $14.5 \times 7.8 \times 6.7$ & 1117 \\
\hline 1923.28.04. & $\begin{array}{l}\text { Large conical blade core, obsidian, with } 19 \text { blade } \\
\text { scars. Cortex on the cusp (approx. 5\%) }\end{array}$ & $14.1 \times 10.6 \times 9.4$ & 2100 \\
\hline 1923.28.05. & $\begin{array}{l}\text { Large conical blade core, obsidian, with } 13 \text { blade } \\
\text { scars. Cortex on the cusp (approx. } 2 \% \text { ) }\end{array}$ & $13.5 \times 8.8 \times 7.3$ & 1312 \\
\hline 1923.28.06. & $\begin{array}{l}\text { Large conical blade core, obsidian, with } 14 \text { blade } \\
\text { scars. Cortex on the cusp (approx. 5\%) }\end{array}$ & $12.5 \times 8 \times 6.4$ & 937 \\
\hline 1923.28.07. & $\begin{array}{l}\text { Large conical blade core, obsidian, with } 15 \text { blade } \\
\text { scars. Cortex on the cusp (approx. 10\%) }\end{array}$ & $12.9 \times 8.9 \times 8.2$ & 1333 \\
\hline 1923.28.08. & $\begin{array}{l}\text { Large conical blade core, obsidian, with } 12 \text { blade } \\
\text { scars. Cortex on the cusp (approx. 5\%) }\end{array}$ & $12.6 \times 6.9 \times 6.5$ & 760 \\
\hline 1923.28.09. & $\begin{array}{l}\text { Large conical blade core, obsidian, with } 13 \text { blade } \\
\text { scars. Cortex on the cusp (approx. 5\%) }\end{array}$ & $11.8 \times 7.7 \times 6.5$ & 887 \\
\hline 1923.28.10. & $\begin{array}{l}\text { Large conical blade core, obsidian, with } 13 \text { blade } \\
\text { scars. Cortex on the cusp (approx. } 5 \% \text { ) }\end{array}$ & $10.8 \times 7.5 \times 6.1$ & 738 \\
\hline 1923.28.11. & $\begin{array}{l}\text { Large conical blade core, obsidian, with } 14 \text { blade } \\
\text { scars. Cortex on the cusp (approx. } 2 \% \text { ) }\end{array}$ & $10.5 \times 7.4 \times 6.3$ & 804 \\
\hline
\end{tabular}

The 11 giant obsidian cores have been analysed at the NIPS-NORMA station of the $2.7 \times 10^{7} \mathrm{n}^{-1} . \mathrm{cm}^{-2}$ intensity intensity horizontal cold neutron beam. Besides the PGAA station for smaller objects, NIPS-NORMA is suitable to accommodate large objects of up to $20 \mathrm{~cm} \times$ $20 \mathrm{~cm} \times 15 \mathrm{~cm}$ (Figure 4).

With a set of beam collimators and with the help of an adjustable sample stage arbitrary parts of the objects can be selected to analyse. For the analysis of obsidian cores, typical acquisition times of 1.0 to 1.5 hours were chosen. In order to perform background correction, a blank measurement without an object was performed, too.

\section{Results}

The quantitative analysis was based on our PGAA library (Révay et al. 2004) using the HYPERMET PC spectrum fitting software (Révay et al. 2005, Révay 2009) and the ProSpeRo 3.2.4 software package used for calculation of elemental concentrations and their uncertainties. With PGAA, we were able to quantify all the major components, such as $\mathrm{SiO}_{2}$, $\mathrm{TiO}_{2}, \mathrm{Al}_{2} \mathrm{O}_{3}$, the total iron oxide, expressed as $\mathrm{Fe}_{2} \mathrm{O}_{3}, \mathrm{MnO}, \mathrm{CaO}, \mathrm{Na}_{2} \mathrm{O}, \mathrm{K}_{2} \mathrm{O}$, and the total $\mathrm{H}_{2} \mathrm{O}$. Particularly, $\mathrm{MgO}$ was found to be below the detection limit of the Budapest PGAA facility. As a convention in geochemistry, major components are given in oxide forms. Besides the major components, some important minor and trace elements, such as $\mathrm{B}, \mathrm{Cl}, \mathrm{Sm}$ and Gd have been quantified, too. Concentration values for major components are given in 
mass $\%$, whereas trace element concentrations are given in $\mu \mathrm{g} / \mathrm{g}$. The results are summarized in Table 2. According to the PGAA measurements, the material of the cores proved to be a high $\mathrm{SiO}_{2}$ content volcanic glass fitting well among Carpathian 1 (C1) obsidian types. Macroscopic qualities and a-priori knowledge on obsidian distribution ( $\mathrm{C} 1$ being most widespread and popular) also indicated this assignment, fully corroborated by geochemical data.

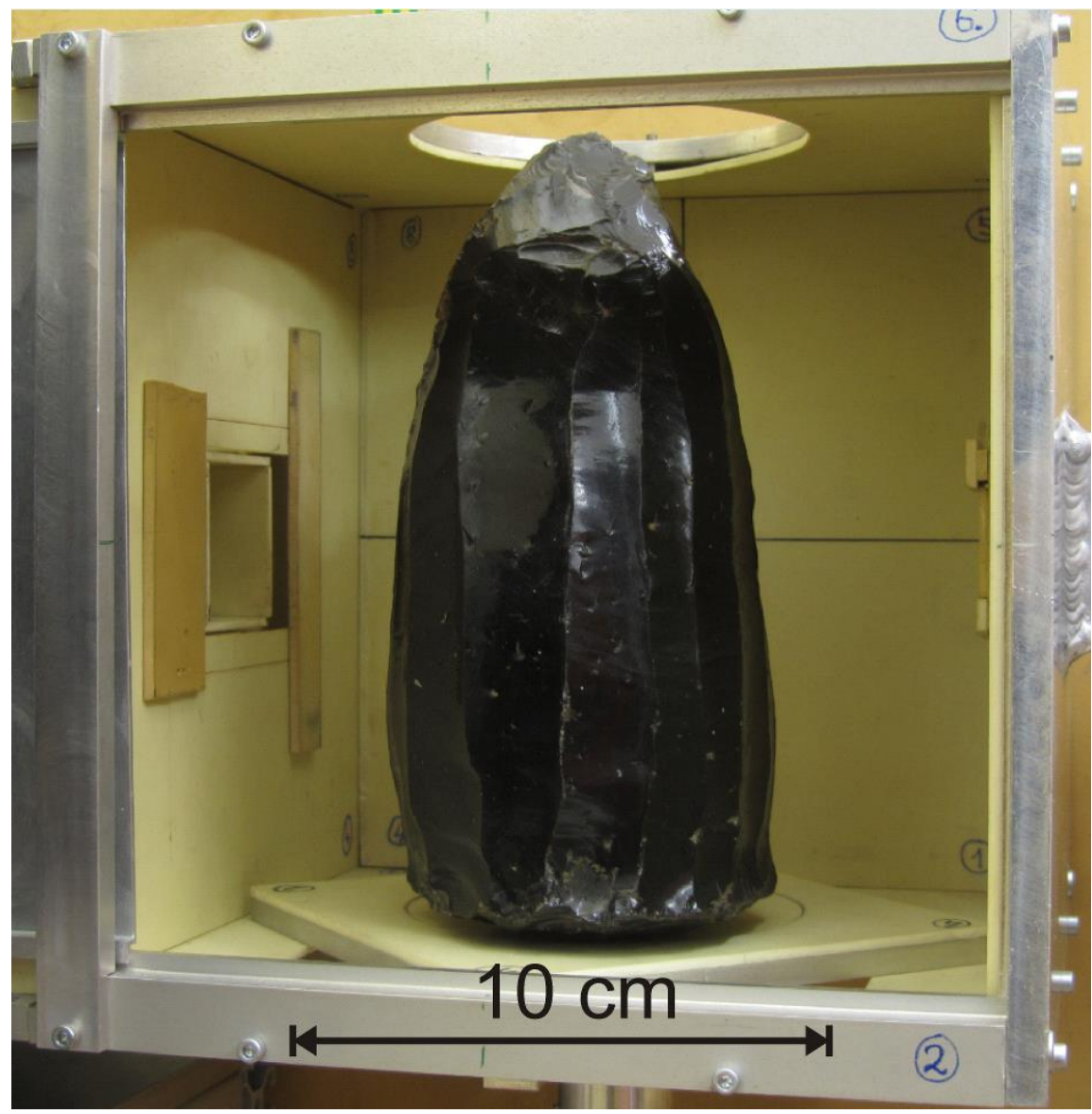

Figure 4. An obsidian core in the sample holder of the Budapest NIPS-NORMA station.

According to bivariate plots of certain elements, as well as Principal Component Analysis and hierarchical cluster analysis, the cores fit in a closely clustered data set. In our earlier studies (Kasztovszky et al. 2008, 2009), we have found that the most characteristic elements for fingerprinting, measurable with PGAA, are B and $\mathrm{Cl}$. As it was expected, B- and $\mathrm{Cl}$-contents of the rocks make possible to determine the provenance of the cores. They fit in a closely clustered data set of Carpathian 1 obsidian type objects (Figures 5 and 6).

Multi-element data analysis techniques, such as Principal Component Analysis (PCA) Figure 7 and Hierarchical Cluster Analysis (HCA), Figure 8. have been used to reveal compositional similarities and differences between obsidians of different origin. On Figure 6, F1 and F2 principal components - the linear combinations of chemical components that maximize the differences among objects - are plotted (Baxter \& Beardah 1995). HCA is also operating on detecting distances in a multi-dimensional space, suggesting certain clusters to be formed among the data set that are closer to each other than the rest of the samples. Values for the Nyírlugos heard compared to geological reference material are plotted on Figure 7. Both statistical methods have provided the same results: The Nyírlugos cores are clustered closely together, unambiguously within the field of Carpathian 1 obsidian and closer to the Viničky subgroup (C1b) than the Kašov-Cejkov subgroup (C1a). 


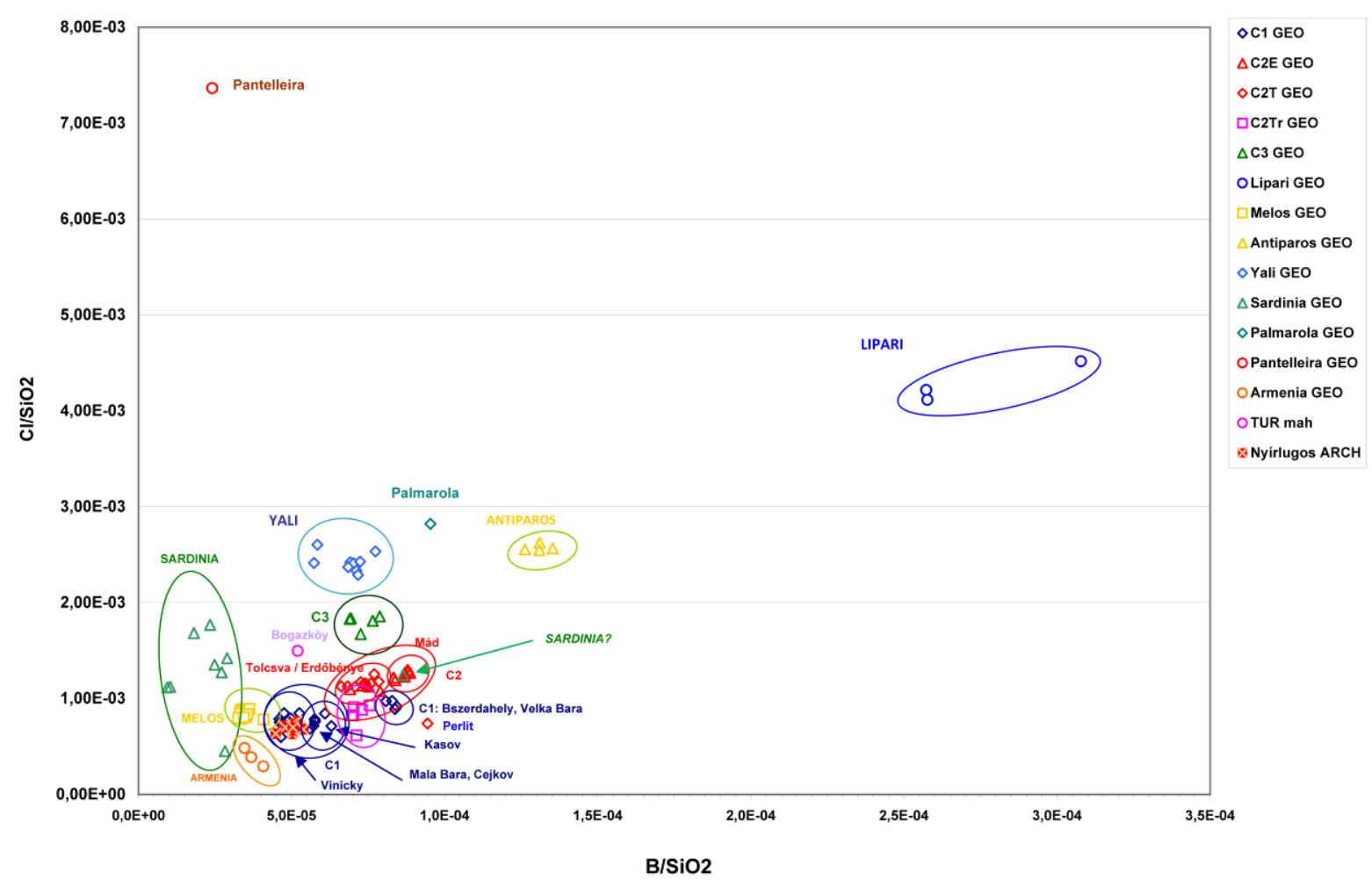

Figure 5. Separation of obsidian source regions on the basis of $\mathrm{B} / \mathrm{SiO}_{2}$ and $\mathrm{Cl} / \mathrm{SiO}_{2}$ mass ratios. The Nyírlugos hoard is compared with geological reference samples.

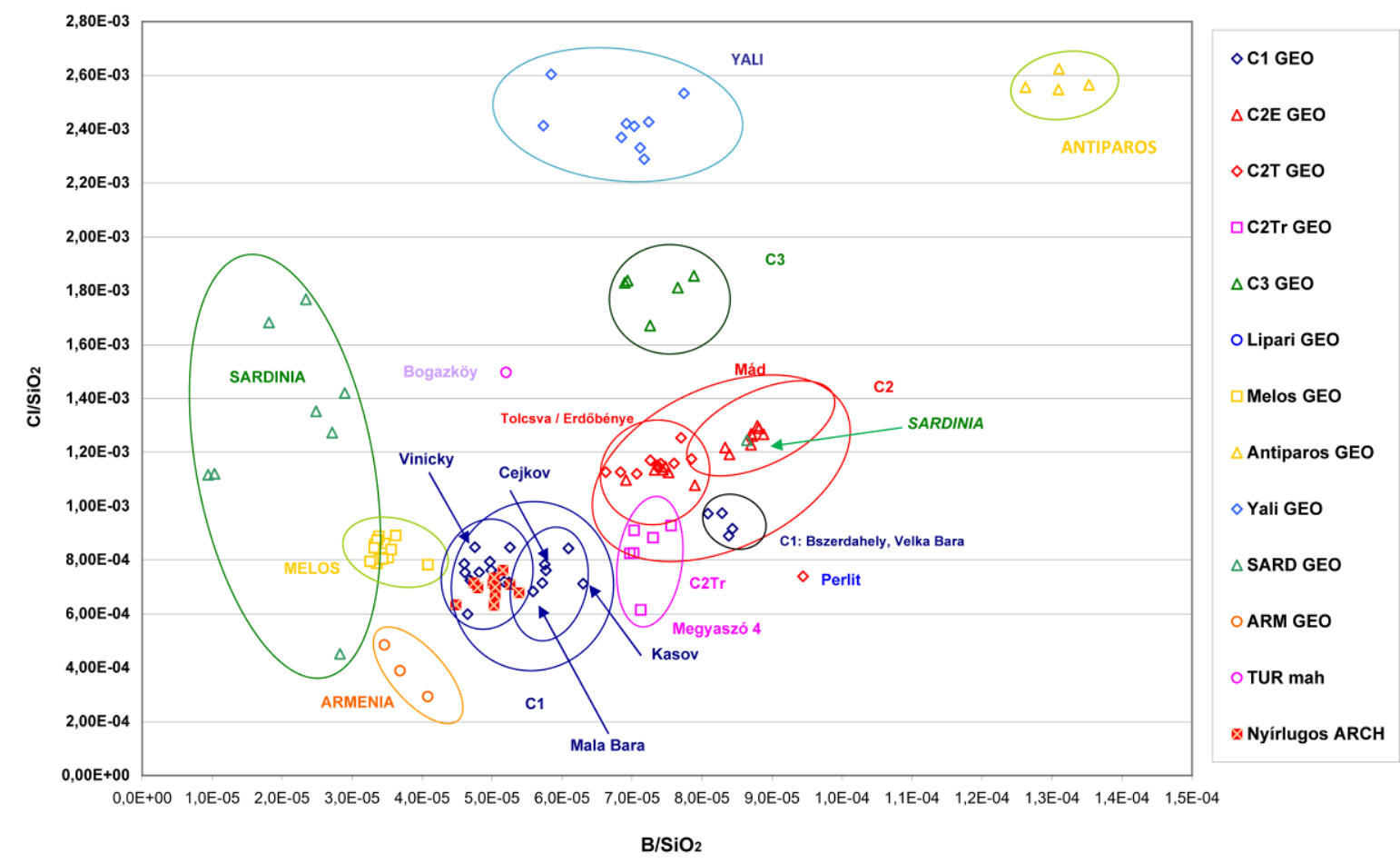

Figure 6. Separation of obsidian source regions on the basis of $\mathrm{B} / \mathrm{SiO}_{2}$ and $\mathrm{Cl} / \mathrm{SiO}_{2}$ mass ratios. The Nyírlugos hoard is compared with geological reference samples - detail of Figure 5. 


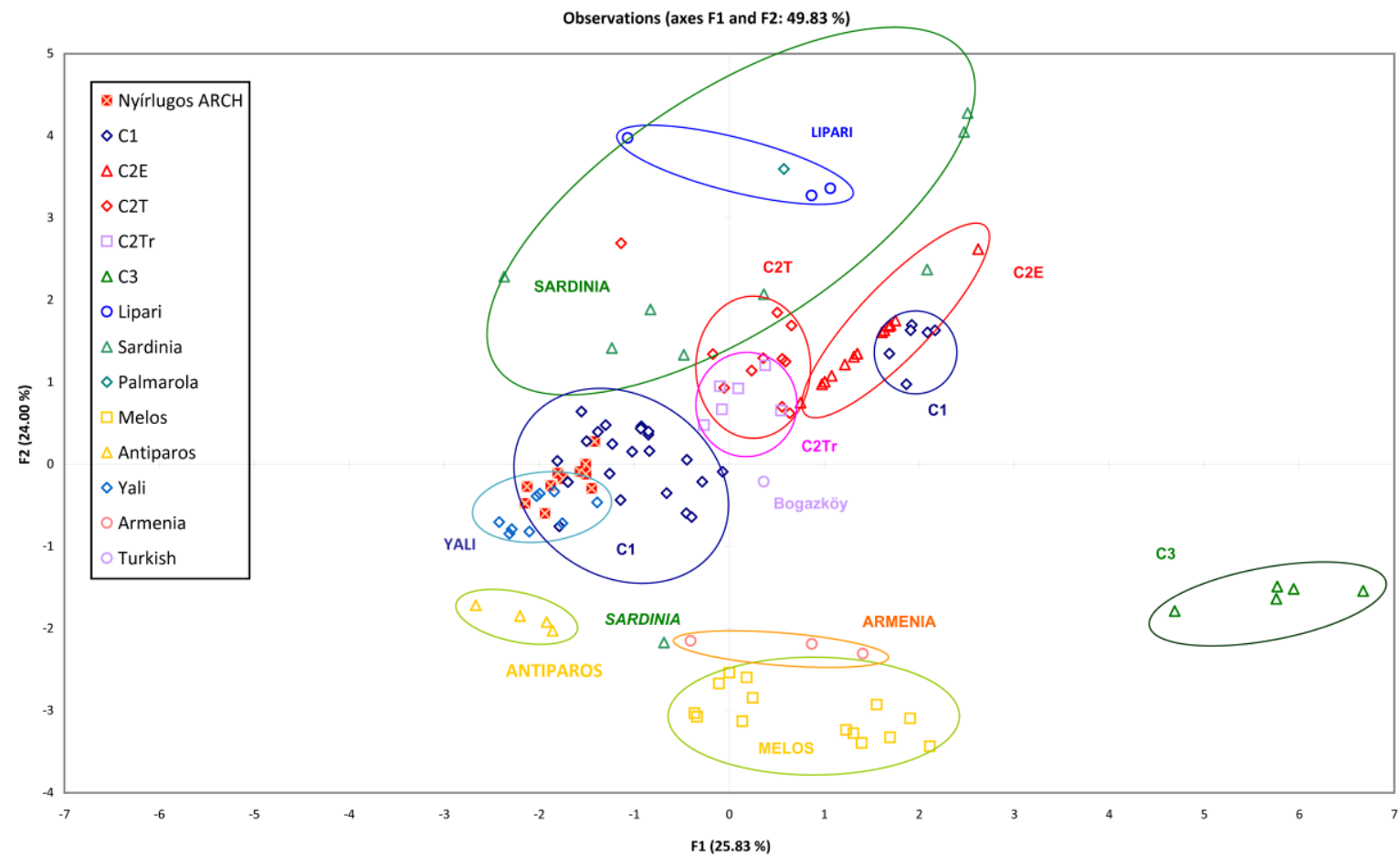

Figure 7. Separation of obsidian source regions on the basis of Factors 1 and 2 of Principal Component Analysis of geochemical data, plotting the Nyírlugos hoard on the graph.

Table 2. Chemical composition data on the of the Nyírlugos cores by PGAA. Concentration values for major components are given in mass\% $(\mathrm{m} \%)$, whereas trace element concentrations are given in $\mu \mathrm{g} / \mathrm{g}$.

\begin{tabular}{|c|c|c|c|c|c|c|c|c|c|c|c|c|c|c|}
\hline $\begin{array}{l}\text { Inventory } \\
\text { number } \\
\text { (HNM) }\end{array}$ & 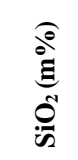 & 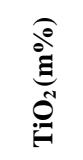 & 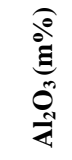 & 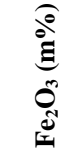 & 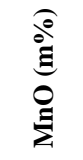 & 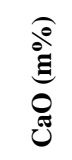 & 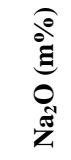 & 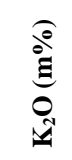 & 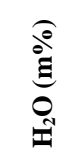 & $\begin{array}{l}\frac{\partial 0}{000} \\
\frac{300}{3} \\
\bar{U}\end{array}$ & 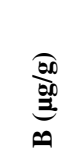 & 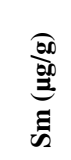 & 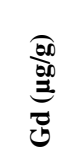 & $\underset{(\mathbf{m} \%)}{\text { SUM }}$ \\
\hline 1923.28.01 & 76.5 & 0.044 & 12.7 & 1.06 & 0.049 & 0.79 & 4.11 & 4.55 & 0.13 & 484 & 38.5 & 3.26 & 3.73 & 99.99 \\
\hline 1923.28.02 & 76.7 & 0.042 & 12.9 & 1.02 & 0.046 & 0.74 & 3.75 & 4.45 & 0.21 & 549 & 38.4 & 3.04 & 3.40 & 99.99 \\
\hline 1923.28.03 & 77.2 & 0.043 & 12.6 & 0.96 & 0.054 & 0.75 & 3.55 & 4.56 & 0.15 & 518 & 38.9 & 2.83 & 3.53 & 99.99 \\
\hline 1923.28 .04 & 76.4 & 0.047 & 13.0 & 1.03 & 0.047 & 0.81 & 3.83 & 4.69 & 0.14 & 583 & 39.4 & 3.36 & 3.83 & 99.99 \\
\hline 1923.28 .05 & 76.6 & 0.048 & 12.9 & 1.05 & 0.051 & 0.85 & 3.82 & 4.48 & 0.17 & 563 & 38.5 & 3.21 & 3.31 & 99.99 \\
\hline 1923.28 .06 & 76.6 & 0.039 & 12.7 & 0.96 & 0.053 & 0.77 & 3.84 & 4.59 & 0.35 & 520 & 41.3 & 2.92 & 3.47 & 99.99 \\
\hline 1923.28.07 & 76.8 & 0.044 & 12.8 & 1.01 & 0.043 & 0.81 & 3.69 & 4.50 & 0.20 & 536 & 36.9 & 3.07 & 3.38 & 99.99 \\
\hline 1923.28 .08 & 76.5 & 0.046 & 12.9 & 1.00 & 0.057 & 0.78 & 3.80 & 4.68 & 0.17 & 543 & 40.2 & 3.05 & 3.75 & 99.99 \\
\hline 1923.28.09 & 76.9 & 0.042 & 12.6 & 1.01 & 0.056 & 0.77 & 3.80 & 4.33 & 0.40 & 551 & 36.5 & 2.65 & 3.73 & 99.99 \\
\hline 1923.28 .10 & 77.4 & 0.047 & 12.5 & 1.02 & 0.048 & 0.77 & 3.66 & 4.38 & 0.14 & 491 & 34.7 & 2.92 & 3.10 & 99.99 \\
\hline 1923.28 .11 & 76.6 & 0.048 & 13.0 & 1.07 & 0.045 & 0.83 & 3.67 & 4.54 & 0.15 & 536 & 38.7 & 2.96 & 3.43 & 99.99 \\
\hline
\end{tabular}




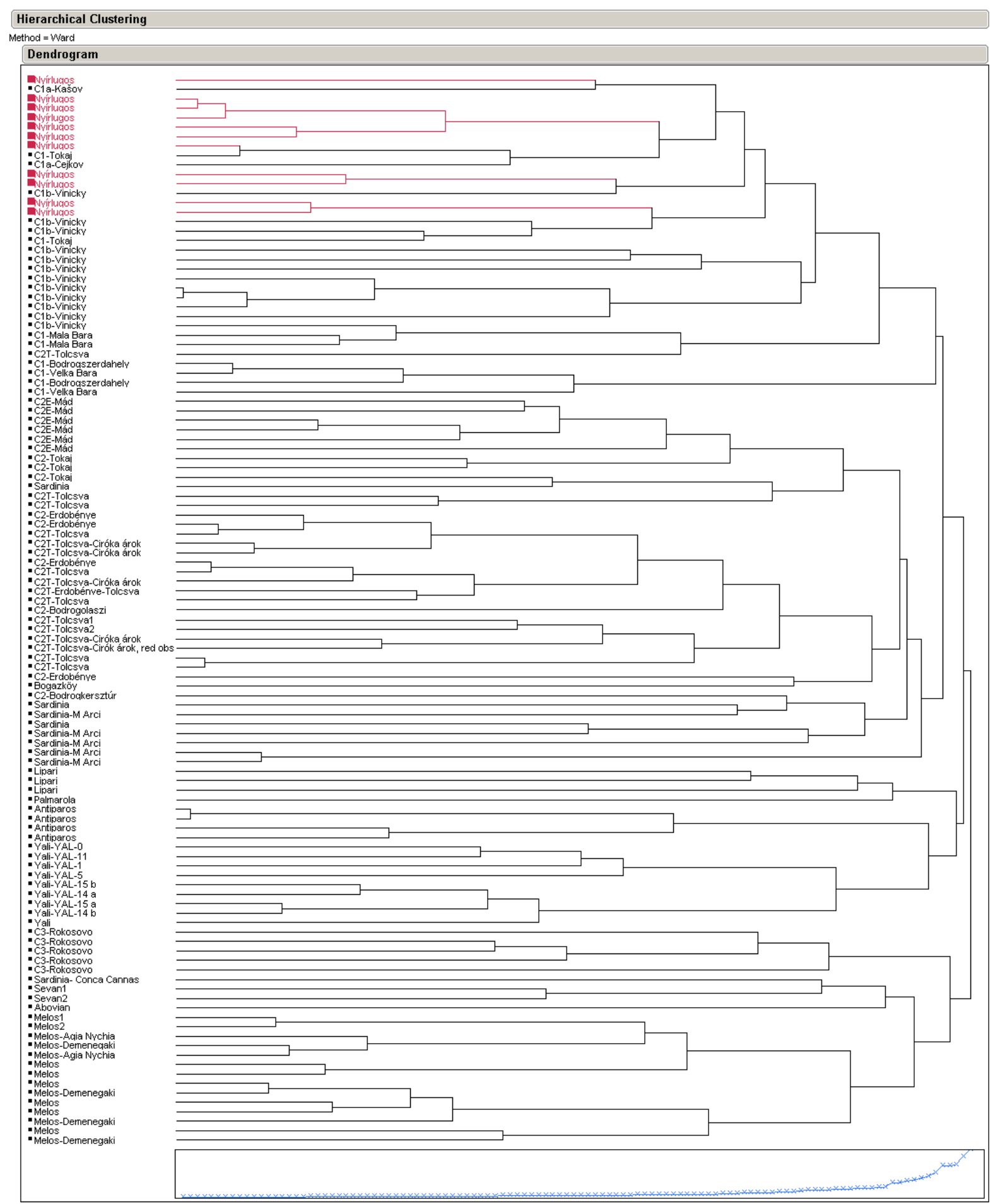

Figure 8. Hierarchical cluster diagram of obsidian sources in the Mediterranean region and the Nyirlugos depot find.

\section{Discussion}

Sources and characterisation of Carpathian obsidians are well known and adequately published (Figure 2) (Williams-Thorpe et al. 1984, Biró 2004, 2006, see also previous references; recent developments in Rosania et al. 2008 and Kaminska 2013). It is clear that the most popular variety, distributed wide and far was Carpathian 1 (=Slovakian) type. The exact source of this obsidian, however, is still unknown - probably due to intensive exploitation. The Kašov and Cejkov environs with large Upper Palaeolithic workshops have 
been treated as „quasi-sources”(C1a). The Viničky outcrop, which is a rich secondary source, was known and characterised $(\mathrm{Clb})$, however, former distribution data indicated the primacy of $\mathrm{C} 1 \mathrm{a}$ variety on the archaeological sites. The current analysis of the Nyírlugos cores, however, yielded results that could be better interpreted as belonging to the $\mathrm{C} 1 \mathrm{~b}$ (Viničky) sources.

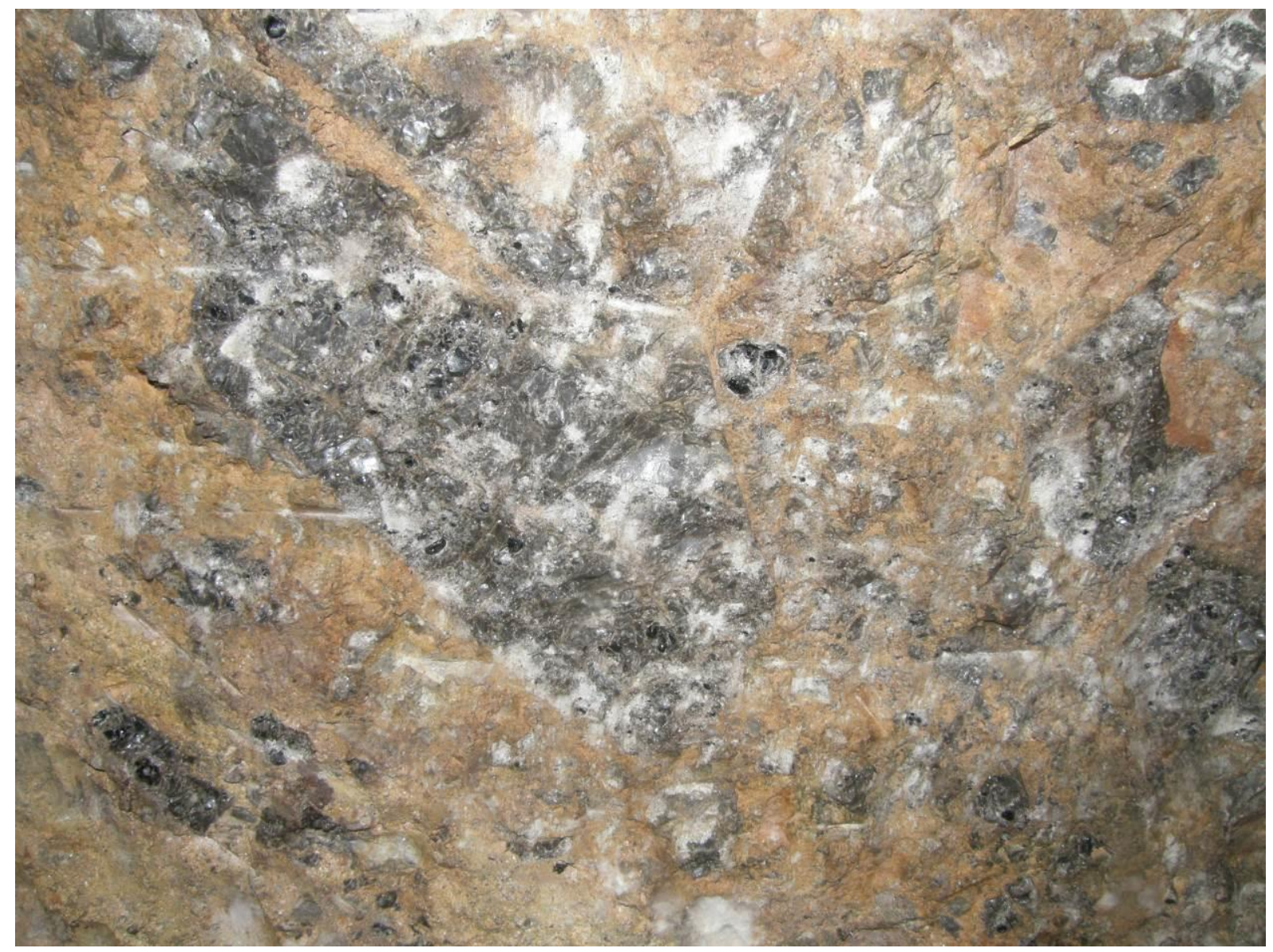

Figure 9. New wine cellar at Vinicky with 10-15 cm large obsidian lumps (black) in rhyolitic (beige) and perlitic lava (grey). (Photo courtesy of P. Solt.)

The possible importance of the Viničky source is underlined by recent topical observations as well. Construction of large underground wine cellars in the immediate vicinity of the well-known obsidian source brought to light large obsidian lumps located in the fresh-cut shafts (Figure 9). This fact let us raise the hypothesis that large obsidian cores known from Middle Neolithic context might have originated from exploiting (quarrying?) such sources.

\section{Conclusions}

The Nyírlugos hoard could be identified clearly as belonging to Carpathian 1 (Slovakian) sources, most probably from the Viničky sub-group (C1b). The study of the hoard as a batch is an important contribution to the assessment of prehistoric trade and allows us to know more about the Carpathian sources, especially the Carpathian 1 (Slovakian) source region. It also allows us to suppose underground mining activity in the territory of the Carpathian source area connected with large-scale exploitation of obsidian, probably in the Middle Neolithic (=LBC and derivatives) period. 


\section{Acknowledgements}

PGAA measurements were done at the Budapest Neutron Centre. The research was funded by Hungarian Scientific Research Fund (OTKA 100385).

\section{References}

Baxter, M. J. \& Beardah, C.C. 1995, Graphical Presentation of Results from Principal Components Analysis. In: Computer Applications and Quantitative Methods in Archaeology, (Huggett J. \& Ryan, N., Eds.), BAR International Series Vol. 600, Tempus Reparatum, Oxford: p. 63-67.

Bánesz, L. 1991, Neolitická dielna na vyrobu obsidiánovej industrie v Kašove, Vychodoslovensky Pravek, Vol. 3. Archeologický ústav SAV, Nitra: 39-68. (in Slovak) ("Neolithic obsidian manufacturing workshop in Kašov")

Biró, K.T. 1987, Chipped stone industry of the Linearband Pottery Culture in Hungary. In: Chipped stone industries of the early farming cultures in Europe, (Kozłowski, J.K., \& Kozłowski, S.K., Eds.), Archaeologia Interregionalis Vol 240, Warsaw-Cracow University press, Cracow: p. 131-167.

Biró, K.T. 1998, Lithic implements and the circulation of raw materials in the Great Hungarian Plain during the Late Neolithic Period, Hungarian National Museum, Budapest, $350 \mathrm{p}$.

Biró, K.T. 2001, The "ham" of Bagódomb. In: Festschrift für Gheorghe Lazarovici, (Draşovean, F., Ed.), Muzeul Banatului, Timisoara: p. 91-122.

Biró, K.T. 2003, Tevel flint: a special constituent of the Central European LBC lithic inventories. In: Production and Management of Lithic Materials in the European Linearbandkeramik, (Burnez-Lanotte, L., Ed.), Actes of the XIVth UISPP Congress, University of Liège, Belgium, 2-8 September 2001, Colloque 9.3, BAR International Series Vol. 1200, Archaeopress, Oxford: p. 11-17.

Biró, K.T. 2004, A kárpáti obszidiánok: legenda és valóság. Archeometriai Mühely, 1(1): 3-8. (in Hungarian) ("Carpathian Obsidians: Myth and reality ") URN: urn:nbn:hu-4106

Biró, K.T. 2006, Carpathian Obsidians: Myth and reality. In: Proceedings of the 34th International Symposium on Archaeometry, 3-7 May 2004., Institución «Fernando el Católico», Zaragoza: p. 267-278. Last accessed: 24 March 2014 URL: http://ifc.dpz.es/recursos/publicaciones/26/10/_ebook.pdf

Hillebrand, J. 1928, A nyirlugosi obsidiannucleus depotleletről. Archaeológiai Értesítö, 42: 39-42. (in Hungarian) ("On the Nyirlugos obsidian core depot find")

Hillebrand, J. 1929, A pusztaistvánházai rézkori temető / Das frühkupferzeitliche Gräberfeld von Pusztaistvánháza,. Archaeologia Hungarica, 4: 1-51. (in Hungarian and in German) ("The Early Copper Age Cemetery at Pusztaistvánháza")

Kaminska, L. 2013, Sources of raw materials and their use in the Palaeolithic of Slovakia. In: Papers of the Visegrád fund project 21110211, (Mester, Z. Ed.), Polish Academy of Arts and Sciences, Kraków and Institute of Archaeological Sciences of the Eötvös Loránd University, Budapest, Kraków-Budapest: p. 99-110. 
Kasztovszky, Z. \& Biró, K.T. 2004, A kárpáti obszidiánok osztályozása prompt gamma aktivációs analízis segítségével: geológiai és régészeti mintákra vonatkozó első eredmények. Archeometriai Mühely, 1(1): 9-15. (in Hungarian) ("Fingerprinting Carpathian Obsidians by PGAA: First results on geological and archaeological specimens") URN: urn:nbn:hu-4106

Kasztovszky, Z. \& Biró, K.T. 2006, Fingerprinting Carpathian Obsidians by PGAA: First results on geological and archaeological specimens. In: Proceedings of the 34th International Symposium on Archaeometry, 3-7 May 2004. Institución «Fernando el Católico», Zaragoza: p. 301-308. Last accessed: 24 March 2014 URL: http://ifc.dpz.es/recursos/publicaciones/26/10/_ebook.pdf

Kasztovszky, Z., Biró, K. T., Markó, A. \& Dobosi, V. 2008, Cold Neutron Prompt Gamma Activation Analysis - a Non-Destructive Method for Characterization of High Silica Content Chipped Stone Tools and Raw Materials. Archaeometry, 50(1): 12-29. doi:10.1111/j.1475-4754.2007.00348.x

Kasztovszky, Z. \& Težak-Gregl, T. 2009, Kora-neolitikus radiolarit és obszidián kőeszközök vizsgálata promptgamma aktivációs analízissel. / Prompt gamma activation analysis of Early Neolithic radiolarite and obsidian stone tools. In: Nyersanyagok és kereskedelem. Öskoros Kutatók VI. Összejövetelének konferenciakötete / Raw materials and trade. Proceedings of the 6th Meeting for the Researchers of Prehistory Köszeg, 2009. március 19 - 21. (Ilon, G., Ed.), Mómósz Vol. 6, Kulturális Örökségvédelmi Szakszolgálat, Budapest and Vas Megyei Múzeumok Igazgatósága, Szombathely: 189196. (in Hungarian with English abstract)

Patay, P. 1960, A kállói kőpenge lelet. / La trouvaille de lames de pierre près de la Commune Kálló,. Folia Archaeologica, 12: 15-20. (in Hungarian and in French) ("The find of stone blades from Kálló")

Patay, P. 1976, Les matières premières lithiques de l'âge du cuivre en Hongrie. Acta Archaeologica Carpathica, 16: 229-238. (in French) ("Lithic raw materials from the Copper Age in Hungary")

Révay, Z. 2009, Determining Elemental Composition Using Prompt Gamma Activation Analysis. Analytical Chemistry, 81: 6851-6859. doi:10.1021/ac9011705

Révay, Z., Belgya, T. \& Molnár, G. L. 2005, Application of Hypermet-PC in PGAA. Journal of Radioanalytical and Nuclear Chemistry, 265: 261-265. doi:10.1007/s10967-005$\underline{0818-2}$

Révay, Z., Firestone, R. B., Belgya, T. \& Molnár, G. L. 2004, Prompt Gamma-ray Spectrum Catalog. In: Handbook of Prompt Gamma Activation Analysis with Neutron Beams, (Molnár, G. L., Ed.), Kluwer Academic Publishers, Dordrecht-Boston-New York : p. 173-364.

Rosania, C.N., Boulanger, M.T., Biró, K.T., Ryzhov, S., Trnka, G. \& Glascock, M.D. 2008, Revisiting Carpathian obsidian,. Antiquity+ (Project Gallery), 82(318). Last accessed: 01 March 2014 URL: http://antiquity.ac.uk/projgall/rosania/

Visy Z., Nagy M., B. Kiss Zs. eds. 2003, Hungarian Archaeology at the turn of the Millennium, Teleki Publishers, Budapest, 482 p. 
Szentmiklósi, L., Kis, Z., Belgya, T. \& Berlizov, A. N. 2013, On the design and installation of a Compton-suppressed HPGe spectrometer at the Budapest neutron-induced prompt gamma spectroscopy (NIPS) facility. Journal of Radioanalytical and Nuclear Chemistry, 298(3): 1605-1611. doi:10.1007/s10967-013-2555-2

Williams-Thorpe, O., Warren, S. E. \& Nandris, J. 1984, The distribution and provenance of archaeological obsidian in Central and Eastern Europe. Journal of Archaeological Science, 11(3): 183-212. doi:10.1016/0305-4403(84)90001-3 
